Original Article

\title{
CHANGES IN HAEMOSTATIC PARAMETERS OF WISTAR RATS FOLLOWING REPEATED ADMINISTRATION OF AQUEOUS EXTRACT OF BROWN ONION (ALLUMCEPAL.)
}

\author{
ZUBERU JIBRIL ${ }^{*}$, SANI SANUSI ${ }^{2}$ \\ ${ }^{1}$ BM Diagnostic Services, Kaura Namoda Zamfara State, ${ }^{2}$ Medical Services Department Federal Polytechnic Kaura Namoda Zamfara State \\ *Email: Abdullahizubairu13@gmail.com
}

Received: 29 Mar 2020, Revised and Accepted: 03 Mar 2021

\section{ABSTRACT}

Objective: The study investigated changes in haemostatic parameters such as; bleeding time, blood clotting time and differential platelet counts of wistar rats following repeated administration of aqueous extract of allum cepa $\mathrm{L}$.

Methods: Rats were divided into four groups of four animals each $(\mathrm{n}=4)$. Group I served as normal control, Group II, group IIIand group IV were administered $25 \mathrm{mg} / \mathrm{kg} \mathrm{bw}, 50 \mathrm{mg} / \mathrm{kg}$ bw and $100 \mathrm{mg} / \mathrm{kg} \mathrm{bw}$ of the extract intra-peritoneally for two weeks, respectively. After $14 \mathrm{~d}$ experimental period, blood samples were collected for the determination of bleeding time, clotting time and differential platelet count.

Results: The findings of this study revealed a significantly increased $(\mathrm{p}<0.05)$ clotting time at a dose of $25 \mathrm{mg} / \mathrm{kg}$ but showed no significant change in bleeding time and differential platelet count of all the groups.

Conclusion: Aqueous extract of brown onion showed anti haemostatic effect in albino rats by increasing clotting time at a lower dose.

Keywords: Bleeding time, Clotting time, Allumcepa, Haemostasis, Rats

(c) 2021 The Authors. Published by Innovare Academic Sciences Pvt Ltd. This is an open access article under the CC BY license (https://creativecommons.org/licenses/by/4.0/) DOI: https://dx.doi.org/10.22159/ijpps.2021v13i5.37673. Journal homepage: https://innovareacademics.in/journals/index.php/ijpps.

\section{INTRODUCTION}

The vascular endothelium is important in the regulation of vascular haemostasis; its alteration has also been suggested to contribute to the pathogenesis of cardiovascular diseases [1]. Platelet aggregation plays a central role in coronary thrombosis and also contributes to the development of atherosclerosis [2]. A blood clot is depended on the balance between pro-coagulants and anticoagulants in the bloodstream. The anticoagulant predominates when a vessel is ruptured while pro-coagulants from the area of tissue damage become activated and override the anticoagulant; thus, clots do not develop [3, 4]. Several studies have reported the effect of specific beverages and foods on inhibiting platelet aggregation, whereas limited works have been reported on beverages and foods stimulating platelet aggregation [5]. Thus,a diet rich in natural platelet stimulators or inhibitors may determine an individual's risk of developing cardiovascular disorders.

Onion is the term used for many plants in the genus "Allum" but usually refers to Allum cepa. It is known only in cultivation; however, related species occur in central Asia [6]. Onion is utilized globally in culinary practice due to its unique flavours in foods that range from very mild to pungent form [7]. It is the second most important crop after tomato. Global production of about 66 million tonnes is achieved annually [8]. Onion contains an organic sulphur compound, phenolic acid, flavanoids, sterols, the trace of volatile oil, vitamin C, vitamin $B_{6}$ and trace elements $[9,10]$. Researchers have shown its wide pharmaceutical applications in the treatment of cancer, inflammation, asthma, oxidative stress, cardiovascular diseases and other health conditions $[4,11-13]$. In addition to these, several works have also investigate the haemostatic effect of some onion varieties. However, there are conflicting views on the role of different onion varieties and genotypeson both platelet and antiplatelet activities using different models [4, 14-19]. Thus, identification of the varieties with better health benefitsis essential in curbing some diet-induced functional and morphological distortions in tissues.

The present study investigated the effect of aqueous extract of Brown Onion (AllumcepaL.) on bleeding, clotting time and differential platelet count of Wistar albino rats.

\section{MATERIALS AND METHODS}

\section{Drugs and chemicals}

All reagents utilized for this study were of analytical grade; Methylated Spirits (Sigma Aldrich Company Ltd, Dorset England), Filter Papers (Rippert and Anlagentechnik GMBH and CO. KG, Herzebrock-clarholz, Germany) Giemsa stain (Sigma Aldrich Company Ltd, Dorset England).

\section{Plant samples collection, identification and extractions}

Fresh brown onions were obtained from samaru market, Zaria Kaduna state, Nigeria. Identification was done at the herbarium unit of Biological Sciences Department, Ahmadu Bello University, Zaria, Nigeria. The voucher number is 2196 . The outermost layer was removed and the onions were sliced using a knife. The sliced onion was put into a blending machine and crushed into a watery paste. Water was added during this process. The onion juice was left for an hour after which it was decanted into an evaporating dish. The evaporating dish was placed into a water bath and heated at 40 degrees Celsius during which there was evaporation from the onion juice. The evaporating dish was left with the concentrated extract. The whole process lasted for $3 \mathrm{~d}$.

\section{Acute toxicity (LD50) test}

The mean lethal dose of aqueous AllumcepaL. was determined in albino rats using the intraperitoneal route as described by Lorke [20]. The LD50 was found to be $1264.9 \mathrm{mg} / \mathrm{kg}$.

\section{Experimental animals}

A total of sixteen albino rats of male sex, weighing 140-180g werepurchased from the faculty of Pharmaceutical sciences,Ahmadu Bello University, Zaria, Nigeria. The animals were housed in steel wire cages in a room where the congenital temperature was $27^{\circ} \mathrm{C} \pm 1{ }^{\circ} \mathrm{C}$ and $12 \mathrm{~h}$ light and dark cycles were maintained. The animals were allowed to acclimatize to the environment for two weeks and supplied with a standard pellet diet and water ad libitum. The study was conducted in accordance with the Ethical Committee Guidelines of the institution on the use of animals for research. 


\section{Animal groupings}

The rats were randomly divided into 4 groups of 4 rats each.

Group I: Normal control received feed and distilled water only for $14 \mathrm{~d}$. Group II: Normal rats treated with aqueous extract of allumcepa L. $25 \mathrm{mg} / \mathrm{kg}$ bw/day intra peritoneally for $14 \mathrm{~d}$.

Group III: Normal rats treated with aqueous extract of allum cepa L. $50 \mathrm{mg} / \mathrm{kg} \mathrm{bw} /$ day intraperitoneally for $14 \mathrm{~d}$. Group IV: Normal rats treated with aqueous extract of allum cepaL. $100 \mathrm{mg} / \mathrm{kg} \mathrm{bw} /$ day intraperitoneally for $14 \mathrm{~d}$.

\section{Determination of bleeding time}

Using the method of Dukes [21], the tail end of the rats was disinfected using a methylated spirit. A scissors was used to cut the tail. The bleeding time of the rats was done by counting the number of spots that blotted on filter paper, multiplied by the number of interval that blotted on the filter paper and divided by 60 seconds.

\section{Determination of clotting time}

Clotting Time was calculated as described by Lee and White [22]; Briefly, the tails ofthe animals from each group were cleaned and disinfected with methylated spirit, then cut with scissors. The tip of the tail of each animal was immediately directed into four plain glass test tubes. $1 \mathrm{ml}$ of blood was taken from the animal and immediately delivered into 4 clean test tubes $(75 \times 10 \mathrm{~mm})$ already standing in a turn every 30 seconds until tilted through an angle greater than 90 without spillage. The electronic stopwatch was started immediately blood starts oozing out of the animal into the test tubes. The average time was then calculated for clotting.

\section{Determination of platelets counts}

The method used is known as Differential count method. Briefly, drops of blood were collected on slides and used to prepare smear.
The smear was fixed in methylalcohol for $3 \mathrm{~min}$. Staining of the slides was done using Giemsa dilution for $20 \mathrm{~min}$. The slides were rinsed using water and then with a buffer of P. H 7.0. Counting of the different types of platelets was determinedusing an amsalco electronic microscope [23].

\section{Statistical analysis}

Data obtained ware expressed as mean $( \pm$ SEM). The result was analysed using one way analysis of Variance(ANOVA), followed by an appropriate post-hoc test to compare the level of significance between groups using SPSS version 17.0. Values of $p<0.05$ was considered significant.

\section{RESULTS}

Effect of acqeous extract of brown onion on bleeding timeof albino rats

There was no statistical significant difference $(p>0.05)$ between the normal control group and all the treated groups as shown in fig. 1.

Effect of acqeous extract of brown onion on clotting timeof albino rat

There was a significant increase $(\mathrm{p}<0.05)$ in clotting time of group treated with $25 \mathrm{mg} / \mathrm{kg}$ of the onion extract when compared to the normal control group $(1.27 \pm 0.04 \mathrm{~min})$, as shown in fig. 2 . The mean clotting time of the treated group at $25 \mathrm{mg} / \mathrm{kg}(2.57 \pm 0.16 \mathrm{~min})$ was significantly increased compared to groups treated with $50 \mathrm{mg} / \mathrm{kg}$ $(1.35 \pm 0.07 \mathrm{~min})$ and $100 \mathrm{mg} / \mathrm{kg}(0.95 \pm 0.15 \mathrm{~min})$ of the extract, respectively.

Effect of acqeous extract of brown onion on differential platelet count of albino rats

There was no statistical significant difference $(p>0.05)$ between the normal control group and all the treated groups, as shown in table 1 .

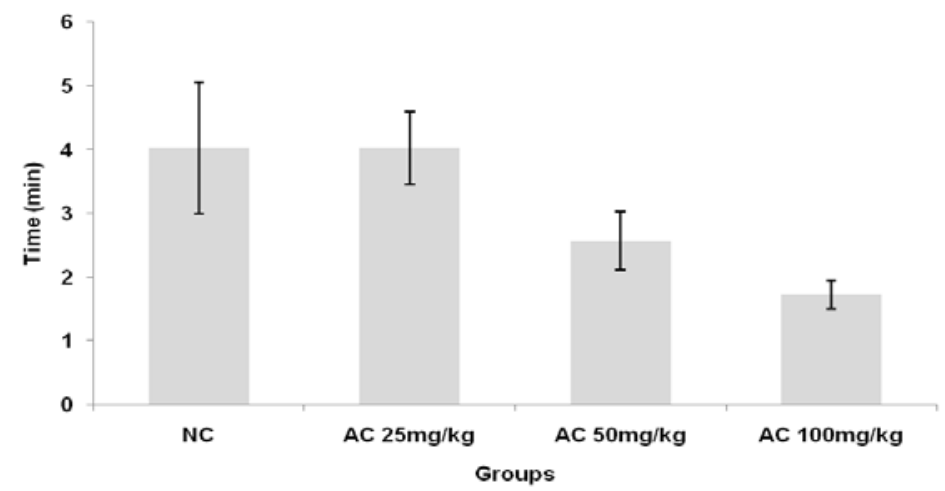

Fig. 1: Effect of acqeous extract of brown onion (allum cepa $\mathrm{L}$.) on bleeding timeof albino rats, Results are expressed as mean \pm standard error of mean $n=5$. Results are expressed as mean \pm standard error of mean $n=5$. NC: Normal Control AC: allum cepaL. No statistical significance between all the groups $(\mathrm{p}>0.05)$

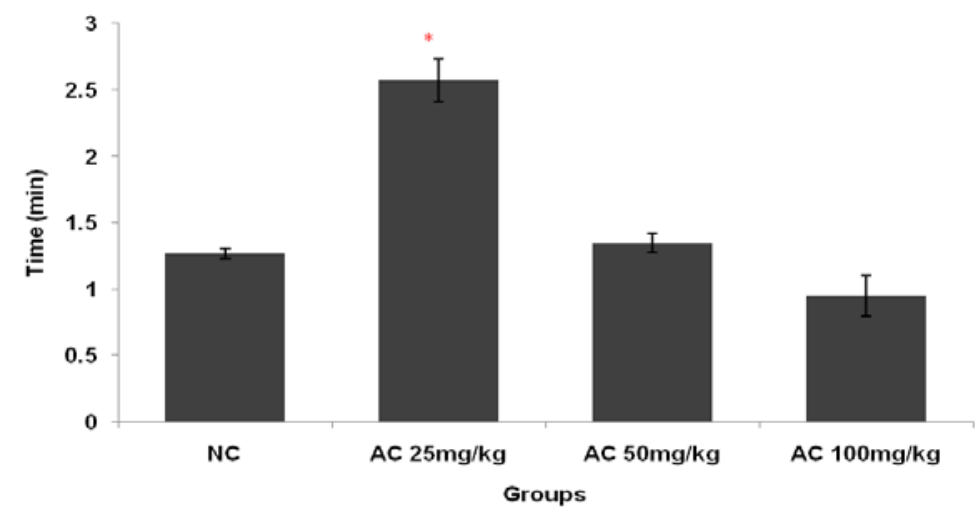

Fig. 2: Effect of acqeous extract of brown onion (allum cepa $\mathrm{L}$.) on clotting time of albino rats, results are expressed as mean \pm standard error of mean $n=5$. NC: Normal Control AC: allum cepaL. Values with superscripts $(*)$ are statistically significant $(p<0.05)$ compared to all other groups 
Table 1: Effect of acqeous extract of brown onion (allum cepa $\mathrm{L}$.) on differential platelet count of albino rats

\begin{tabular}{llll}
\hline Groups (n=4) & NP/100 & AP/100 & FP/100 \\
\hline NC & $19.50 \pm 2.66$ & $16.75 \pm 1.37$ & $18.500 \pm 1.93$ \\
AC25 mg/kg & $18.75 \pm 1.60$ & $16.25 \pm 1.31$ & $19.000 \pm 1.35$ \\
AC50 mg/kg & $18.50 \pm 1.55$ & $16.25 \pm 1.31$ & $18.750 \pm 1.49$ \\
AC50 mg/kg & $19.50 \pm 1.32$ & $18.00 \pm 1.47$ & $18.250 \pm 1.03$ \\
\hline
\end{tabular}

${ }^{*}$ Results are expressed as mean \pm standard error of mean $\mathrm{n}=5$. NC: Normal Control AC: allum cepaL. NP: Normal Platelet, AP: Aggregated Platelets, FP: Filamentous Platelet, PA: Platelets Anisocytosis. No statistical significance between all the group ( $p>0.05)$.

\section{DISCUSSION}

Haemostasis is a fundamental and complex defence mechanism of all vertebrates. The process of haemostasis requires multiple interdependent interactions between platelets, endothelial cells, white cells and plasma proteins [24]. Blood normally remains in the liquid state while it is within the blood vessels, but when it leaves the vessels, the blood may thicken and form a gel and subsequently transform into a solid state. It is one of the three mechanisms in haemostasis which denotes the cessation of blood loss from a damaged vessel [4]. Platelets are essential during haemostatic process; when they are activated during endothelial cells damage, platelets aggregate, and adhere to the lining of arteries [17, 25] Following a break in the endothelial lining, there is an initial adherence of platelets to exposed connective tissue which is potentiated by von Willibrand factor (VWF). Platelets begin to aggregate minutes after activation as a result of turning on the glycoprotein IIb/IIIa receptors which will in turn bind to von Willibrand factor [26]. Collagen exposure and thrombin produced at the site of injury cause the adherent platelets to release their granule contents and also activate platelet prostaglandin synthesis, leading to the formation of thromboxane A2 [27]. Releasing Adenosine Diphosphate (ADP) causes platelets to swell and aggregate. Additional platelets from the circulating blood are drawn to the area of injury. This continuing platelet aggregation promotes the growth of the haemostatic plug which soon covers the exposed connective tissue $[4,27]$. However, hyperactivity of platelets can contribute to arthrosclerosis formation, coronary syndrome, peripheral vascular diseases, stroke and thrombosis $[17,25]$. The present study was carried out to determine the potentials of brown onion variety on the haemostatic mechanism of albino rats, with primary interest on how it affects bleeding, clotting time and differential platelets count respectively. From the results above, there was a significant increase in the clotting time with the tendencies to also increase bleeding time at $25 \mathrm{mg} / \mathrm{kg}$ (table 1 ). A previous study using the same variety of allumcepa $L$. to determine its effects on clotting time on pigs yielded small but insignificant result with platelet number unaffected [28]. Chen et al.[15] reported fromtheir study thatonion prolonged bleeding time, diminished platelet adhesion on fibrinogen coated surface ADP evoked platelet aggregation, ADP stimulated thromboxane release, elevated cyclic AMP in plateletsand increased the plasma level of 6-keto-prostaglandin F. Compounds that have been implicated in providing a number of health promoting attributes of onions include flavanoids, particularly the quercetin and organosulphur compound such cysteine sulphoxide [29]. The number of quercetin and phenolic compounds present in onion skin are up to 5 times higher than the edible part [9]. The inhibitory effect of dietary flavanoids on platelet function has been recognized for some time, with recent reports showing the identity of specific targets of collagen mediated signalling pathways that leads to platelets activation, are inhibited by quercetin in vitro. This includes Src-family kinases, tyrosine kinase and phosphoinositide-3-kinase [31]. Despite these effects, there are mixed results documented concerning the effect of flavanoidsin take and cardiovascular risk [1]. Also, research work carried out to determine whether all onion varieties have natural antithrombotic effect as assessed by thrombosis/thrombolysis models in rodents, showed that allumcepa can be classified into varieties; with or without antithrombotic activity [19]. The ability of brown onion to increase both bleeding and clotting time from our studymay be due to its active ingredients with a direct or indirect effecton the clotting cascade as it correlates to the study of Chen et al.[15]. Also observed from this study, is dose-dependent decrease is bleeding and clotting time (fig. 1 and 2).
Hence, aqueous brown onion extract may decrease bleeding and clotting time at higher doses. There was no significant difference in the differential platelet count of wistar rats after repeated administration of aqueous onion extract (table 1). Our results contradict the findings of Ro et al.,[17], but may align with the findings of Ewaet al.[28] and Meraiyebuet al.[32]. This difference may be attributed to the onion variety [33], the percentage composition of active ingredients, geographical distribution and study design. Whilein vitro effect of aqueous extract of onion on collagen-induced platelet aggregation using rabbit and human platelet-rich plasma, resulted in dose-dependent inhibitory effects on collagen-induced platelets [34], in vitro incubation of onion juice demonstrated that platelet inhibitory response was significantly greater than in human blood [2]. The effect of onion in vitro platelet activity was reported to be time-dependent [35].

\section{CONCLUSION}

Aqueous extract of brown onion variety (allumcepa L.)possessed anti haemostatic property at a low dose $(25 \mathrm{mg} / \mathrm{kg})$. This is evidenced by a significant increase in clotting time of albino rats following repeated administration. People with bleeding disorders are therefore advised to reduce the consumption of brown onion. Phytochemical studies and isolation of active ingredients of this onion variety may help in evaluating its potential health hazards and/or benefits.

\section{ACKNOWLEDGEMENT}

The authors acknowledge the participation of technicians of the Department of Human Physiology Ahmadu Bello University, Zaria, Nigeria.

\section{FUNDING}

Nil

\section{AUTHORS CONTRIBUTIONS}

Research design and analysis were done by Jibril Zuberu while Sanusi Sani discussed the results and made recommendations.

\section{CONFLICT OF INTERESTS}

Authors have declared that no competing interests exist.

\section{REFERENCES}

1. Vita JA. Polyphenols and cardiovascular disease: effects on endothelial and platelet function. AJCN 2005;81:292S-7.

2. Briggs WH, Folts JD, Osman HE, Goldman IL. Administration of raw onion inhibits platelet-mediated thrombosis in dogs. Nutr J 2001;131:2619-22.

3. Dahlbäck B. Blood coagulation. Lancet 2000;355:1627-32.

4. Guyton AC, Hall JC. A textbook of medical physiology. $11^{\text {th }}$ ed. WB Sanders. Company Philadelphia; 2006. p. 457-67.

5. Hansen EA, Folts JD, Goldman IL. Steam-cooking rapidly destroys and reverses onion-induced antiplatelet activity. Nutr J 2012;11:76.

6. Grubben GJ, Denton OA. Plant resources of tropical Africa 2. Vegetables. PROTA Foundation, Wageningen, Netherlands. backhuys Publishers, Leiden, Netherlands/CTA, Wgeningen Netherlands. Available from: https://www/hort.purdue/ edu/newcrop.duke_energy/moringa,htm. [Last accessed on 10 Apr 2004.

7. Crowther T, Collin HA, Smith B, Tomsett AB, O'Connor D, Jones MG. Assessment of the flavour of fresh uncooked onions by 
taste-panels and analysis of flavour precursors, pyruvate and sugars. J Sci Food Agric 2005;85:112-20.

8. Omer HA, El-Mallah GM, Abdel-Magid SS, Bassuony NI, Ahmed SM, El-Ghamry AK. Impact of adding natural bioactive mixture composed of lemon, onion, and garlic juice at different levels on productive performance, egg quality, and some blood parameters of commercial laying hens. Bull Net Res Cent 2019;43:137.

9. Ncayiyana M, Maboko MM, Bertling I. Yield and nutritional quality of different short-day onion cultivars as affected by nitrogen application. S Afr J Plant Soil 2018;35:215-21.

10. Verma M, Singh SS, Rose NM. Phytochemical screening of onion skin (Allium cepa) dye extract. J Pharmacogn Phytochem 2018;7:1414-7.

11. Helen A, Rajasree CR, Krishnakumar K, Augusti KT, Vijayammal PL. Antioxidant role of oils isolated from garlic (Allium sativum Linn) and onion (Allium cepa Linn) on nicotine-induced lipid peroxidation. Vet Hum Toxicol 1999;41:316-9.

12. Fukushima S, Takada N, Hori $\mathrm{T}$, Wanibuchi H. Cancer prevention by organosulfur compounds from garlic and onion. J Cell Biochem 1997;67:100-5.

13. Roldan Marin E, Jensen RI, Krath BN, Kristensen M, Poulsen M, Cano MP, et al. An onion by product affects plasma lipids in healthy rats. J Agric Food Chem 2010;58:5308-14.

14. Furusawa M, Tsuchiya H, Nagayama M, Tanaka T, Nakaya KI, Iinuma M. Anti-platelet and membrane-rigidifying flavonoids in brownish scale of onion. J Health Sci 2003;49:475-80.

15. Chen JH, Chen HI, Tsai SJ, Jen CJ. Chronic consumption of raw but not boiled Welsh onion juice inhibits rat platelet function. Nutr J 2000;130:34-7.

16. Weisenberger $\mathrm{H}$, Grube $\mathrm{H}$, Koenig E, Pelzer $\mathrm{H}$. Isolation and identification of the platelet aggregation inhibitor present in the onion, Allium CEPA. FEBS Lett 1972;26:105-8.

17. Ro JY, Ryu JH, Park HJ, Cho HJ. Onion (Allium cepa L.) peel extract has anti-platelet effects in rat platelets. Springer Plus 2015;4:17.

18. Hubbard GP, Wolffram S, de Vos R, Bovy A, Gibbins JM, Lovegrove JA. Ingestion of onion soup high in quercetin inhibits platelet aggregation and essential components of the collagenstimulated platelet activation pathway in man: a pilot study. $\mathrm{Br}$ J Nutr 2006;96:482-8.

19. Yamada K, Naemura A, Sawashita N, Noguchi Y, Yamamoto J. An onion variety has natural antithrombotic effect as assessed by thrombosis/thrombolysis models in rodents. Thromb Res 2004;114:213-20.

20. Lorke D. A new approach to practical acute toxicity testing. Arch Toxicol 1983;54:275-87.

21. Duke WW. The relation of blood platelets to hemorrhagic disease: description of a method for determining the bleeding time and coagulation time and report of three cases of hemorrhagic disease relieved by transfusion. JAMA Intern Med 1910;55:1185-92.
22. Lee RI, White PD. A clinical study of the coagulation time of blood. Am J Med Sci 1913;145:495.

23. Dennett TB, Hawkey CM, Peirce MA. A colour atlas of comparative veterinary haematology: normal and abnormal blood cells in mammals, birds and reptiles. Wolf Publishing Ltd Ipswich England; 1989. p. 139-41.

24. Davison C, Levendal R, Frost C. Cardiovascular benefits of an organic extract of Tulbaghiaviolacea: Its anticoagulant and anti-platelet properties. J Med Plant Res 2012;6:4815-24.

25. Mann LB, Folts JD. Effects of ethanol and other constituents of alcoholic beverages on coronary heart disease: a review. Pathophysiology 2004;10:105-12.

26. Yip J, Shen Y, Berndt MC, Andrews RK. Primary platelet adhesion receptors. IUBMB Life 2005;57:103-8.

27. Coleman RW, Hirsh J, Marder VJ, Clowes AW, George JN. Hemostasis and thrombosis: basic principles and clinical practice. $4^{\text {th }}$ edn. Lipincott, Williams and Wilkins, Hagerstown; 2000. p. 320-3.

28. Ewa ONK, Gabler SJ, Sterling BG, Tatham RB, Jones DR, Eagling $\mathrm{MJ}$, et al. Dunshea consumption of brown onions (Allumcepa var. Cavalier and var. Destiny) moderately modulates blood lipids, haematological and hemostatic variables in healthy pigs. Br J Nutr 2004;911:211-8.

29. Price KR, Rhodes MJ. Analysis of the major flavanol glycosides present in four onion varieties of onion (Allumcepa) and changes in ccomposition resulting from autolysis. J Sci Food Agric 1997;74:331-3.

30. Verma M, Singh SS, Rose NM. Phytochemical screening of onion skin (Allium cepa) dye extract. J Pharmacogn Phytochem 2018;7:1414-7.

31. Hubbard GP, Stevens JM, Cicmil M, Sage T, Jordan PA, Williams $\mathrm{CM}$, et al. Quercetin inhibits collagen-stimulated platelet activation through inhibition of multiple components of the glycoprotein VI signaling pathway. J Thromb Haemost 2003;1:1079-88.

32. Meraiyebu AB, Olaniyan OT, Anjorin YD, Shekins O, Dare BJ, Shafe MO. Effects of aqueous extract of onion (Allium cepa) on blood parameters in adult wistar rats (Rattusnovergicus). IOSR Int J Pharm Biol Sci 2013;5:71-4.

33. Rahmat A, Leng CY, Bakar FI, Bakar MF. Effect of red onion (Allium cepa var. aggregatum g. don) on serum uric acid level and total antioxidant status in normal and induced hyperuricemic rats. Asian J Pharm Clin Res 2018;11:178-83.

34. Ali M, Bordia T, Mustafa T. Effect of raw versus boiled aqueous extract of garlic and onion on platelet aggregation. Prostaglandins, Leukotrienes and Essential Fatty Acids (PLEFA). Prostag Leukotr Ess 1999;60:43-7.

35. Osmont KS, Arnt CR, Goldman IL. Temporal aspect of onion induced antiplatelet activity. Plants foods Hum Nutr 2003;58:27-40. 